\title{
Spatiotemporal variation in postlarval recruitment of the Caribbean spiny lobster in the central Bahamas: lunar and seasonal periodicity, spatial coherence, and wind forcing
}

\author{
David B. Eggleston ${ }^{1, *}$, Romuald N. Lipcius ${ }^{2}$, Livingston S. Marshall $\mathrm{Jr}^{3}$, \\ Stephen G. Ratchford ${ }^{1}$ \\ 'North Carolina State University, Department of Marine, Earth and Atmospheric Sciences, Raleigh, \\ North Carolina 27695-8208, USA \\ ${ }^{2}$ The College of William and Mary, School of Marine Science, Gloucester Point, Virginia 23062, USA \\ ${ }^{3}$ Morgan State University, Biology Department, Baltimore, Maryland 21239, USA
}

\begin{abstract}
A large-scale recruitment study of the Caribbean spiny lobster Panulirus argus in the central Bahamas identified (1) strong spatial coherence in settlement to inshore nursery habitats, (2) temporal variability due in part to stochastic wind forcing, and (3) lunar and seasonal periodicity in settlement. First, we quantified lunar variation in settlement on standardized artificial substrates to determine whether or not intra- and inter-annual variability in recruitment could be adequately described by measuring influx of postlarvae during the first quarter of each new moon, as suggested by previous studies. Next, we compared settlement data obtained from artificial surface substrates to concentrations of postlarvae in the water column and benthic settlement. Long-term (6 yr) spatiotemporal variation in postlarval settlement was then quantified at 8 sites spanning a longitudinal and onshore distance of $43 \mathrm{~km}$ and $11 \mathrm{~km}$, respectively. Lastly, we examined the relationship between postlarval settlement and environmental variables with time-series analyses. The key findings were that: (1) significant lunar (first quarter of lunar phase) and seasonal (fall peak) periodicities in settlement were consistent across sites; (2) postlarval settlement varied more across sites $(-600 \%)$ than between years at a single site $(\sim 50 \%)$, and inter-site differences were consistent across time (i.e. some sites always had higher settlement than others); (3) settlement was correlated with along-shore winds blowing towards the southeast, but not with cross-shelf winds or water temperature, (4) floating. 'Witham-type' artificial settlement substrates yielded an accurate index of postlarval concentration and flux past a given point; and (5) floating substrates were a relatively poor indicator of benthic settlement, though the relationship between surface and benthic settlement may depend upon benthic habitat availability and postlarval supply. These results indicate that artificial settlement substrates provide a reliable index of postlarval supply to inshore nursery habitats, and that a combination of stochastic and deterministic forces influence recruitment over various scales of time and space.
\end{abstract}

KEY WORDS: Environmental forcing - Panulirus argus - Larval supply $\cdot$ Recruitment $\cdot$ Settlement Spiny lobster

\section{INTRODUCTION}

In marine species with complex life cycles, larval and postlarval supply is influenced primarily by physical factors that vary in a stochastic manner (e.g. meteoro-

•E-mail: eggleston@ncsu.edu logical or oceanographic processes) and result in density-independent survival (Paulik 1973, Fogarty et al. 1991, Higgins et al. 1997). In contrast, the abundance of juveniles and adults is often regulated by densitydependent, post-settlement processes such as predation, cannibalism, and dispersal (Paulik 1973, Caley et al. 1996, Higgins et al. 1997). Whether populations are 
limited by pre-settlement processes, whereby concentrations of larvae or postlarvae are too low to saturate resources, or regulated by density-dependent post-settlement processes often varies according to the spatiotemporal scales of study (review by Caley et al 1996). Extreme variation in recruitment (i.e. the number of new individuals within a population that survive to a specific size, age, or ontogenetic stage) is characteristic of many finfish and invertebrate fisheries (Caddy \& Gulland 1983, Sissenwine 1984), and often masks the effects of overexploitation, thereby hampering management efforts (Ludwig et al. 1993). Understanding recruitment variation requires information on spatiotemporal dynamics of pre- versus post-settlement processes.

Identifying patterns and processes underlying postlarval recruitment dynamics of benthic and demersal marine species should substantially improve our understanding of the relative importance of larval and postlarval supply to population dynamics, and aid in the formulation of predictive population and fisheries models. For example, larval settlement of the bay scallop Argopecten irradians concentricus on artificial spat collectors has been used to track spatial coherence in settlement patterns and subsequent juvenile abundance in Bouge Sound, North Carolina, USA (Peterson \& Summerson 1992), and to test whether or not recruitment limitation of scallops in certain areas could be mitigated through large-scale transplanting of spawning adults (Peterson et al. 1996). Similarly, the Western Australian rock lobster Panulirus cygnus fishery can be accurately predicted $5 \mathrm{yr}$ in advance by quantifying postlarval settlement on artificial substrates (Phillips 1986, Phillips \& Booth 1994). Thus, for some species, the abundance of settlers directly projects juvenile and adult abundances (see also Connell 1985, Gaines \& Roughgarden 1985, Bertness et al. 1992, Milicich et al. 1992, Eggleston \& Armstrong 1995, review by Caley et al. 1996), thereby providing a powerful research and management tool for ecologists and resource managers. In this study, we focus on postlarval recruitment of the Caribbean spiny lobster Panulirus argus. Specifically, we examine variation in settlement over several scales of time (days, months, years) and space (10s of $\mathrm{m}, \mathrm{km}, 10 \mathrm{~s}$ of $\mathrm{km}$ ), and quantify the relationship between settlement and periodic lunar and stochastic meteorological phenomena.

\section{Life history of the Caribbean spiny lobster}

The Caribbean spiny lobster Panulirus argus (Crustacea: Decapoda: Palinuridae) is a widely distributed marine benthic omnivore, and is one of the most commercially important species in the Caribbean,
Bahamas and South Florida, USA (Bohnsack et al 1994, Phillips et al. 1994 and references therein). Its complex life history is typical of marine invertebrates with planktonic larvae. $P$. argus exhibits 5 major phases within the life cycle: adult, egg, phyllosoma larva, puerulus postlarva, and juvenile (Lipcius \& Cobb 1994 and references therein). Adults frequently aggregate during the day in crevices of coral and rocky reefs at deeper depths (Berrill 1975, Herrnkind et al. 1975). Egg masses are spawned and hatched in the spring and summer (approx. March to July) from offshore reef areas. Subsequently, the early phyllosoma-larval stages reside in oceanic waters for approximately 6 to 11 mo (Lyons 1980). Genetic variability among P. argus collected from various regions in the Caribbean and Florida is extremely low, suggesting substantial gene flow between hydrodynamically connected populations during their extended larval phase (Silberman et al. 1994). The last planktonic stage metamorphoses into the postlarva (puerulus), a transparent, free-swimming, non-feeding stage that migrates via oceanic currents and directed swimming to inshore areas, where it settles to the benthos (Calinski \& Lyons 1983). Postlarval influx typically occurs during nocturnal flood tides during the first lunar quarter, with seasonal or episodic trends in settlement (Little 1977, Little \& Milano 1980, Marx 1986, Ward 1989, Bannerot et al. 1991, BrionesFourzan 1994, Acosta et al. 1997). Postlarval influx of a related species, the western rock lobster Panulirus cygnus, in Australia, is correlated with the Southern Oscillation Index, coastal sea level, sea surface temperature, salinity, and rainfall (as an index of storms) (Phillips et al. 1991, Caputi \& Brown 1993). Patterns in spatial coherence and environmental control of postlarval recruitment in $P$. argus are not well understood (see Acosta et al. 1997).

Until recently, quantifying annual fluctuations in Panulirus argus postlarval recruitment has been difficult due to sampling inconsistencies and lack of longterm sampling at fixed locations (Marx 1986, Acosta ei al. 1997). Recruitment of $P$. argus postlarvae in the Caribbean and Florida has been measured using floating, artificial settlement substrates that mimic benthic vegetation (Witham et al. 1968, Little 1977, Little \& Milano 1980, Marx 1986, Bannerot et al. 1991, BrionesFourzan 1994, Forcucci et al. 1994, Herrnkind \& Butler 1994, Acosta et al. 1997). In Florida Bay, postlarval settlement on modified 'Witham-type', artificial settlement substrates correlated with planktonic abundance and settlement of postlarvae at regional scales of tens of kilometers, but not at local scales of tens of meters (Butler \& Herrnkind 1992). Abundance of $P$. argus juveniles in Florida Bay also correlated with postlarval supply, as measured with artificial settlement substrates, to the region 8 mo earlier (Forcucci et al. 1994). 
Moreover, Australian fishery researchers have used settlement data generated from artificial substrates to successfully predict harvest of the western Australian rock lobster (Phillips 1986, Caputi \& Brown 1993). Thus, artificial settlement substrates may be a useful tool for estimating spatiotemporal variation in postlarval supply to shallow nursery habitats. Nevertheless, although Acosta et al. (1997) is one of the few studies that have examined postlarval recruitment of $P$. argus over relatively long time scales ( $8 \mathrm{yr}$ ) at a single site there is no information on whether or not such longterm settlement patterns are temporally coherent across multiple sites.

In this study, we quantified lunar variation in settlement to determine whether or not intra- and interannual variability in recruitment could be adequately described by measuring influx of pueruli during the first quarter of each new moon, as suggested by previous studies (Acosta et al. 1997 and references therein).
We then examined the relevance of settlement data obtained from modified 'Witham-type' substrates (Little \& Milano 1980) to concentrations of pueruli in the water column, as well as benthic settlement. Having these results allowed us to assess our 2 primary goals: (1) to quantify long-term (6 yr) spatiotemporal variation in postlarval settlement at 8 sites spanning a longitudinal distance of $43 \mathrm{~km}$ in the central Bahamas, and (2) to assess environmental controls on recruitment using time-series analyses.

\section{METHODS AND MATERIALS}

Field site. Postlarval settlement was measured in the Exuma Cays, Bahamas, along the western edge of Exuma Sound within the vicinity of Lee Stocking Island (LSI; $23^{\circ} 45^{\prime} \mathrm{N}, 76^{\circ} 10^{\prime} \mathrm{W}$; Fig. 1). Exuma Sound is a deep $(3000 \mathrm{~m})$, semi-enclosed basin, approxi-

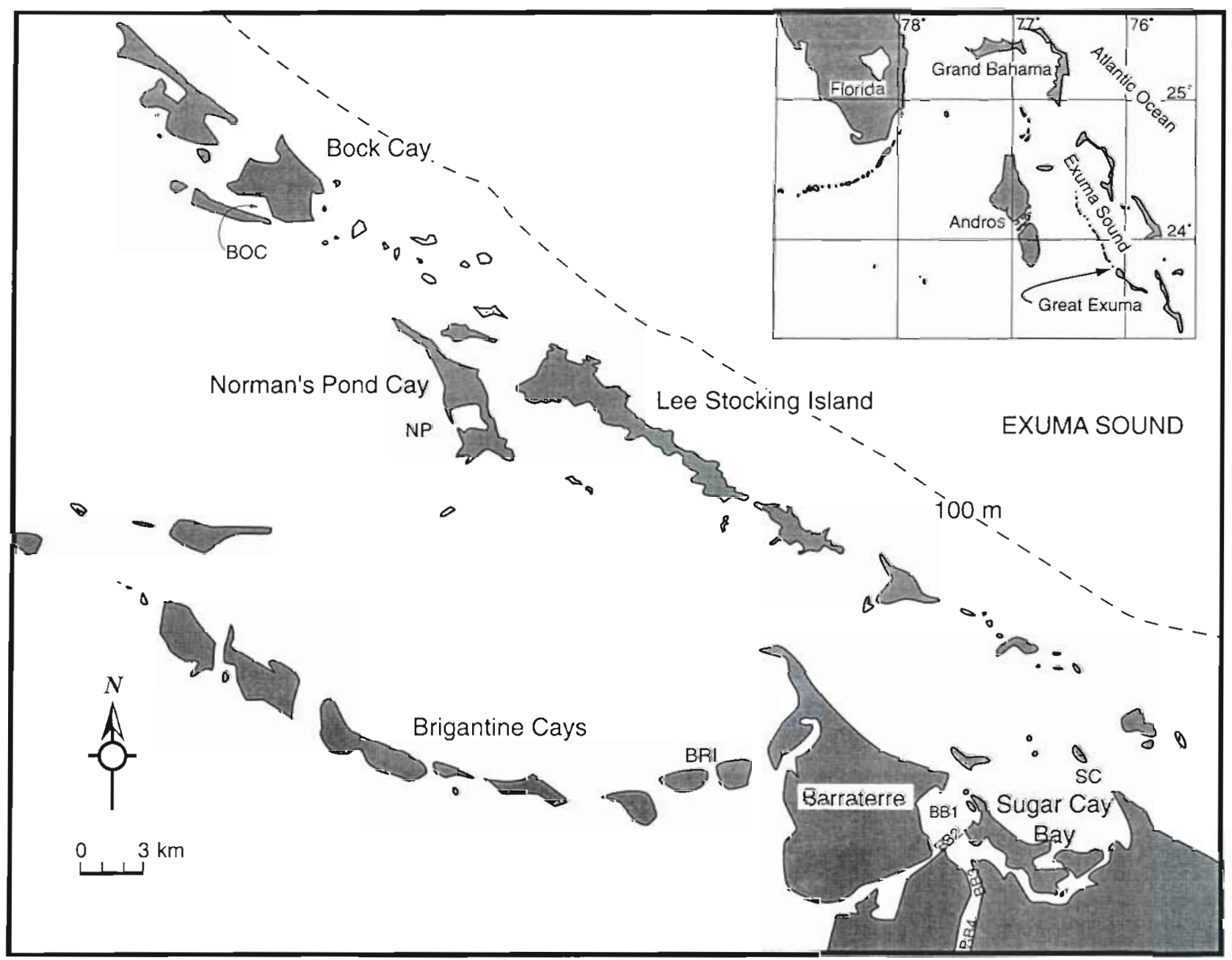

Fig. 1. Study sites near Lee Stocking Island, Bahamas. Macroalgal sites in Barraterre Bay are denoted by BB1, BB2, BB3, BB4 Seagrass sites are denoted as SC (Sugar Cay), NP (Norman's Pond), and BRI (Brigantine Cays). An inter-island channel containing sand at Bock. Cay is denoted as BOC 
mately $200 \mathrm{~km}$ long and $50 \mathrm{~km}$ wide. It is bounded by nearly vertical walls rising to within $30 \mathrm{~m}$ of the surface, and a 1-to 5-km-wide shelf that supports coral reef habitats. The western side of Exuma Sound is bordered by a chain of several hundred small islands known as the Exuma Cays, which separate the Sound from the broad, shallow Great Bahama Bank. The bank averages 3 to $4 \mathrm{~m}$ depth and contains seagrass (Thalassia testudinum) meadows, macroalgal beds, sand and patch coral habitats. The Brigantine Cays are located $\sim 10 \mathrm{~km}$ west of LSI, and between the Exuma Cays and the Great Bahama Banks (Fig. 1). Detailed descriptions of the various habitats within the vicinity of LSI may be found in Herrnkind \& Lipcius (1989), Eggleston (1995), and Eggleston et al. (1997, 1998b).

Circulation in Exuma Sound consists of a mesoscale eddy field superimposed on a northwestward drift (Colin 1995), and is dominated by large-scale gyres extending to depths of up to $200 \mathrm{~m}$ from the sea surface (B. Hickey, University of Washington, unpubl, data). The current speed of the along-shore flow off LSI is $2.4 \mathrm{~cm} \mathrm{~s}^{-1}$ (N. Smith, Harbor Branch Oceanographic Institute [HBOI], unpubl. data). This general northwestward flow is periodically interrupted in the upper $10 \mathrm{~m}$ of the water column during the passage of cold fronts, whose northerly winds produce a strong onshore component of motion (Shenker et al. 1993). Tides are semi-diurnal and strong tidal currents average $8.6 \mathrm{~cm} \mathrm{~s}^{-1}$ with a net displacement towards the Great Bahama Bank (N. Smith unpubl. data).

Lunar periodicity in settlement. We quantified postlarval settlement on modified 'Witham-type', artificial settlement substrates (Little \& Milano 1980) every $3 \mathrm{~d}$ from 7 June to 2 October 1990 at 4 sites near LSI (Fig. 1): Sugar Cay (SC), Barraterre Bay (BB1), Bock Cay (BOC), and the Brigantine Cays (BRI). A sampling period of $3 \mathrm{~d}$ was chosen based on previous observations that settled pueruli metamorphose to the first benthic instar and often emigrate from the floating substrates $3 \mathrm{~d}$ after settlement (J. Hunt, Florida Department of Environmental Protection, Marathon, Florida, USA, unpubl. data). Substrates were constructed of a square, $2 \mathrm{~cm}$ diameter PVC-pipe frame $(55 \mathrm{~cm}$ length $X$ $40 \mathrm{~cm}$ width) with 6 PVC-pipe cross-bars. The crossbars supported individual rectangular sheets $70 \mathrm{~cm}$ length $\times 40 \mathrm{~cm}$ width) of air-conditioning-filter material, which were folded over and secured to each crossbar. Each substrate therefore had a settlement area of $1680 \mathrm{~cm}^{2}$. Substrates were moored to the seafloor with concrete blocks, and floated on the surface with the aid of 2 floats and a marker buoy. Each substrate was retrieved from the water during the day with a mesh bag (2 $\mathrm{mm}$ mesh), and the number of postlarvae counted separately by 2 observers. Carapace length of each postlarva was measured to the nearest $0.1 \mathrm{~mm}$.
'Postlarvae' included individuals that were transparent or those pigmented individuals whose thorax was compressed dorso-ventrally. Three sampling sites were located south of LSI and along a distance gradient corresponding to the trajectory of flood tidal currents carrying postlarvae from Exuma Sound to the Bahama Banks (N. Smith unpubl. data). Sugar Cay Bay (SC) is a seagrass-dominated embayment which would intercept pueruli before they reached the macroalgadominated nursery system in Barraterre Bay (BB1) (Fig. 1). The Brigantine Cays (BRI) site is located downstream of $\mathrm{SC}$ and $\mathrm{BB} 1$ during flood tide, and is characterized by seagrass beds on the flanks of an interisland channel (Fig. 1). The fourth site, Bock Cay (BOC), is located north of LSI in an inter-island passage characterized by shallow depths (1 to $2 \mathrm{~m}$ ), a sand bottom, and high tidal current speeds.

A 2-way, complete block ANOVA was used to examine the effects of month (June to September), which served as the blocking factor, location $(\mathrm{SC}, \mathrm{BB} 1, \mathrm{BOC}$, $\mathrm{BRI})$ and lunar quarter ( $1=$ lunar days 27 to $4 ; 2=$ lunar days 5 to $11 ; 3=$ lunar days 12 to $19 ; 4=$ lunar days 20 to 26) on postlarval catch-per-unit-effort (CPUE; postlarvae substrate $\mathrm{d}^{-1}$ ), which was pooled within a particular lunar phase. These divisions of the lunar cycle account for the amount of illumination and variation in tidal currents that postlarvae would encounter (Mense et al. 1995). Sampling locations and days were each treated as fixed factors since locations were systematically chosen based on pilot studies near LSI (D. Eggleston unpubl. data), and because only three $3 \mathrm{~d}$ sampling intervals were available within each quarter of the lunar phase. Mean CPUE was $\log (x+1)$-transformed to equalize variances. Post hoc multiple comparisons were conducted with a Ryan's Q-test (Day \& Quinn 1989). The ANOVA approach, whereby mean settlement was pooled within lunar quarters, was chosen over time series analysis of individual sampling dates due to the relatively short time period ( 4 separate lunar periods $\times 4$ months) of measurement for this component of our study (Wei 1990). The blocking factor accounted for variation in settlement over time.

Relationship between planktonic concentration of pueruli, settlement on surface substrates, and benthic settlement. We assessed the relevance of settlement data obtained from modified 'Witham-type' artificial settlement substrates in estimating relative postlarval influx by simultaneously quantifying planktonic density and settlement of pueruli on surface substrates once per month in 6 months. Two components of planktonic density, concentration (no. $\mathrm{m}^{-3}$ ) and flux (no. $\mathrm{h}^{-1}$ ) of pueruli, were measured on the west side of a bridge spanning a tidal creek in Barraterre Bay (site BB2; Fig. 1); during flood tide this site was located 50 to $200 \mathrm{~m}$ downstream of sites where surface settlement 
was measured (sites BB1 and BB2; Fig. 1). Planktonic density was measured with paired plankton nets $1 \mathrm{~m}$ apart during new moon, nocturnal flood tides. Each net was constructed of $2 \mathrm{~mm}$ mesh, and filtered an area $50 \mathrm{~cm}$ wide by $100 \mathrm{~cm}$ in height $\left(0.5 \mathrm{~m}^{2}\right)$. Each net contained a flowmeter (General Oceanics model 2030) and fished passively from the bridge for approximately $3 \mathrm{~h}$; water volumes filtered per sample ranged from 256 to $483 \mathrm{~m}^{3}$. Although filtration efficiency for plankton nets of the same design (but with $1 \mathrm{~mm}$ mesh) were approximately $90 \%$ for blue crab (Callinectes sapidus) postlarvae in Chesapeake Bay (Olmi 1994), we do not know whether or not net avoidance by strong-swimming Caribbean spiny lobster pueruli was a problem in this study. Nevertheless, our primary goal was to compare relative rates of puerulus density in the plankton and settlement on surface substrates, and so we assumed that plankton nets provided valid measurements for statistical comparisons between gear types. Plankton were sampled in September and October, 1992, as well as during January to March and May, 1993 ( $\mathrm{n}=6$ ). Four surface substrates were located approximately $20 \mathrm{~m}$ apart at each of 2 sites (BB1 and BB2; Fig. 1). The numbers of settled postlarvae were quantified the morning following plankton sampling. The artificial surface substrates were deployed $3 \mathrm{~d}$ prior to sampling

We analyzed the relationship between postlarval density (concentration and flux) and settlement on artificial substrates with linear least-squares regression. The results of a Durbin-Watson test $(W=2.09)$ and visual examination of autocorrelation and partial autocorrelation functions indicated that there was no autocorrelation in the residuals. Measures of postlarval concentration or flux on one day were related to settlement on artificial substrates the next day. Although examination of the residuals for puerulus flux were suggestive of an exponential relationship between postlarval supply and settlement on floating substrates, Fisher's transformation indicated that exponential or power functions did not significantly improve the fit of the plankton and settlement data over linear functions (all $p>0.31$ ). Thus, we chose the simpler, linear model for examining the relationship between planktonic concentrations of postlarvae and subsequent settlement on floating substrates.

The relationship between benthic and surface settlement of postlarvae was estimated at 3 sites (Norman's Pond [NP], SC and BB1) on a monthly basis from March 1991 to June 1992 using arrays of mesh bags $(71 \mathrm{~cm}$ length $\times 61 \mathrm{~cm}$ width $\times 2 \mathrm{~cm}$ mesh) filled with air-conditioning-filter material ('hogs-hair') and modified 'Witham-type' surface substrates, respectively. We did not quantify benthic settlement in natural habitats because the highest densities of settled postlarvae recorded in this area are extremely low $(\bar{x}=1$ postlarva per $40 \mathrm{~m}^{2}$; D. Eggleston \& R. Lipcius unpubl. data). The benthic substrates contained the same amount of filter material as the surface substrates, and were moored to the seafloor with concrete blocks and suspended from the bottom to approximately $70 \mathrm{~cm}$ above the seafloor with floats. This configuration was intended to mimic clumps of macroalgae (primarily Laurencia sp.) with a high vertical profile; these are common in Barraterre Bay (Eggleston 1995). SCUBA divers transported each benthic substrate to the surface in a mesh bag $(2 \mathrm{~mm}$ mesh) to avoid losing pueruli by disturbance. The number of pueruli in benthic substrates was quantified in the same manner as described above for surface substrates, whereby 2 observers checked each substrate twice. A total of 4 benthic and 4 surface substrates were located approximately $20 \mathrm{~m}$ apart at all 3 sites; the substrates sampled passively $3 \mathrm{~d}$ prior to sampling. We removed short-term autocorrelations from the 16 mo time series of surface and benthic settlement by fitting an 'autoregressive integrated moving average' (ARIMA) time series model to the mean puerulus CPUE data. We then checked whether or not the distribution of residuals was randomly distributed with a Shapiro-Wilk test.

Spatiotemporal variation and environmental control of settlement. Puerulus settlement on artificial substrates was measured once every $3 \mathrm{~d}$ during peak settlement during the first quarter of each new moon ( $\mathrm{n}=3 \mathrm{mo}^{-1}$ ). We chose to sample during the first quarter of the new moon because this study (see 'Results: lunar periodicity') and others (Marx 1986, Bannerot et al. 1991, Briones-Fourzan 1994) have identified highest settlement during the first quarter of the lunar phase. A total of 8 sites within the vicinity of LSI (Fig. 1) were sampled on a monthly basis for 2.5 to $6 \mathrm{yr}$ depending upon the site. Each site contained a total of 4 to 8 substrates; the substrates were located approximately $20 \mathrm{~m}$ apart. The 8 sites spanned a longitudinal distance of $43 \mathrm{~km}$ parallel to the Exuma Cays, and an offshore-onshore distance of $11 \mathrm{~km}$ (Fig. 1). Substrates were sampled and the number of pueruli enumerated as described above. Sites at SC and BB1 and BB2 were sampled monthly for 6 yr (February 1990 to April 1995). Sites at the BRI and BOC were sampled from April 1990 to March 1993 and April 1995, respectively. Substrates at NP were sampled monthly from March 1991 to September 1995. Two additional sites in Barraterre Bay were sampled on a monthly basis beginning in either July 1992 (BB3) or September 1993 (BB4) and continuing through May 1995

Measurements of wind direction and velocity were used to evaluate the role of meteorological conditions on settlement of pueruli. Wind data were collected hourly throughout most of the study period by a Camp- 
bell Scientific weather station located at the LSI airstrip, and daily averages were computed from the daily readings. The daily wind vectors were broken down into cross-shelf and along-shore components for data analyses. Water temperature was also measured hourly throughout most of the study period with an in situ thermistor placed beneath a dock on the west side of LSI; daily averages were calculated from the hourly readings. We did not examine the relationship between puerulus settlement and the hours of dark flood tide', which has been shown to be an important variable affecting recruitment in other studies in this area (Shenker et al. 1993, Thorrold et al. 1994), because sampling was conducted only during the first quarter of each new moon.

The mean number of postlarvae per substrate per day (CPUE) was the response variable in all statistical analyses except those dealing with the relationship between settlement and environmental variables (wind forcing and water temperature). Data were $\log (x$ +1 )-transformed when necessary to meet assumptions of normality and homogeneity of variance. We tested whether or not mean annual CPUE from the 3 sites with the longest annual time series (SC, BB1, BB2; sampled May 1990-1995) was significantly different between years with a 1-way ANOVA. A 1-way ANOVA was also used to determine if mean CPUE (pooled across time) varied between all sites. We examined spatial coherence in settlement by first fitting the CPUE data to various orders of ARIMA models to remove both short-term autocorrelations and longer-term cyclic activity ('pre-whitening'), followed by cross-correlation analyses.

To examine the relationship between settlement and environmental variables (i.e. wind forcing and water temperature), we analyzed data from the 3 sites (SC, $\mathrm{BB} 1, \mathrm{BB} 2$ ) with the longest annual time series. Seasonal periodicity in the data (see 'Results') was removed by calculating a 'pueruli anomaly' using anomalies from the monthly, 5 yr means (e.g. Wei 1990 , Phillips et al. 1991). The pueruli anomaly was simply the difference between the mean CPUE for a given sampling date and the mean CPUE for the 5 yr time series for the same sampling date. We then examined the relationship between the pueruli anomaly and environmental variables (along-shore and cross-shelf wind speeds, water temperature) with an autoregression procedure. Model choice was based on examination of autocorrelation and partial autocorrelation plots of the model residuals, and a number of diagnostic statistics including a Shapiro-Wilk test for normality, and the Durbin-Watson statistic for autocorrelation. Only significant correlations between time series where wind data led puerulus settlement by $6 \mathrm{~d}$ are presented. No biological or physical interpretation could be given to leads greater than $6 \mathrm{~d}$ or to lags (Shenker et al. 1993, Thorrold et al. 1994, N. Smith \& P. Pitts, HBOI, unpubl. data).

\section{RESULTS}

\section{Lunar periodicity}

Postlarval settlement of Panulirus argus was highest during the first and second quarters of the lunar phase at all 4 sampling sites; this pattern was significant for the 2 sites with highest settlement (Table 1, Fig. 2), though the remaining sites showed a similar trend. The blocking factor (month) was not significant (Table 1 ).

\section{Relationship between planktonic density, settlement on surface substrates, and benthic settlement of postlarvae}

Settlement of postlarvae on surface substrates correlated significantly with planktonic concentration and flux of postlarvae at the 2 upstream sites in Barraterre Bay (Fig. 3).

Benthic settlement of postlarvae was correlated with settlement on surface substrates at SC (Fig. 4), but not BB1 $(F=0.23 ; \mathrm{df}=1,14 ; \mathrm{p}=0.64)$ and $\mathrm{NP}(F=3.70 ; \mathrm{df}=$

Table 1. (a) Two-way, complete block ANOVA results (model I) for the effects of Lunar quarter ( $1=$ lunar days 27 to $4 ; 2=$ lunar days 5 to $11 ; 3=$ lunar days 12 to $19 ; 4=$ lunar days 20 to 26) and sampling Site (Sugar Cay, Barraterre Bay [BB1], Bock Cay, and Brigantine Cays) upon $\log (x+1)$-transformed catch-per-unit-effort (CPUE; postlarvae substrate ${ }^{-1} \mathrm{~d}^{-1}$ ) of pueruli pooled within a particular lunar phase. $n=4$ to $5 .^{\circ} p<$ 0.001 ; ns: not significant. (b) Ryan's $Q$-tests of $\log (x+1)$-transformed mean CPUE for the Lunar quarter $\times$ Site interaction effects. Treatment levels that are not significantly different at the 0.05 level share an underline. Treatment levels are arranged in increasing order of CPUE

\begin{tabular}{|c|c|c|c|c|}
\hline & \multicolumn{4}{|c|}{ Source of variation } \\
\hline & SS & df & MS & $F$ \\
\hline \multicolumn{5}{|l|}{ (a) ANOVA } \\
\hline Month (blocking factor) & 0.02 & 3 & 0.01 & $1.92 \mathrm{~ns}$ \\
\hline Lunar quarter & 0.17 & 3 & 0.06 & $27.66^{\circ}$ \\
\hline Site & 0.06 & 3 & 0.02 & $9.01^{\circ}$ \\
\hline Lunar quarter $\times$ Site & 0.07 & 9 & 0.01 & $4.02^{\circ}$ \\
\hline Error & 0.09 & 45 & 0.01 & \\
\hline \multicolumn{5}{|l|}{ (b) Ryan's Q-tests } \\
\hline Site & \multicolumn{4}{|c|}{ Lunar quarter } \\
\hline Sugar Cay & $\underline{4}$ & 3 & 2 & $\underline{1}$ \\
\hline Barraterre Bay & 4 & 3 & 2 & 1 \\
\hline Bock Cay & $\underline{4}$ & 3 & 1 & $\underline{2}$ \\
\hline Brigantine Cay & 4 & 3 & 1 & 2 \\
\hline
\end{tabular}



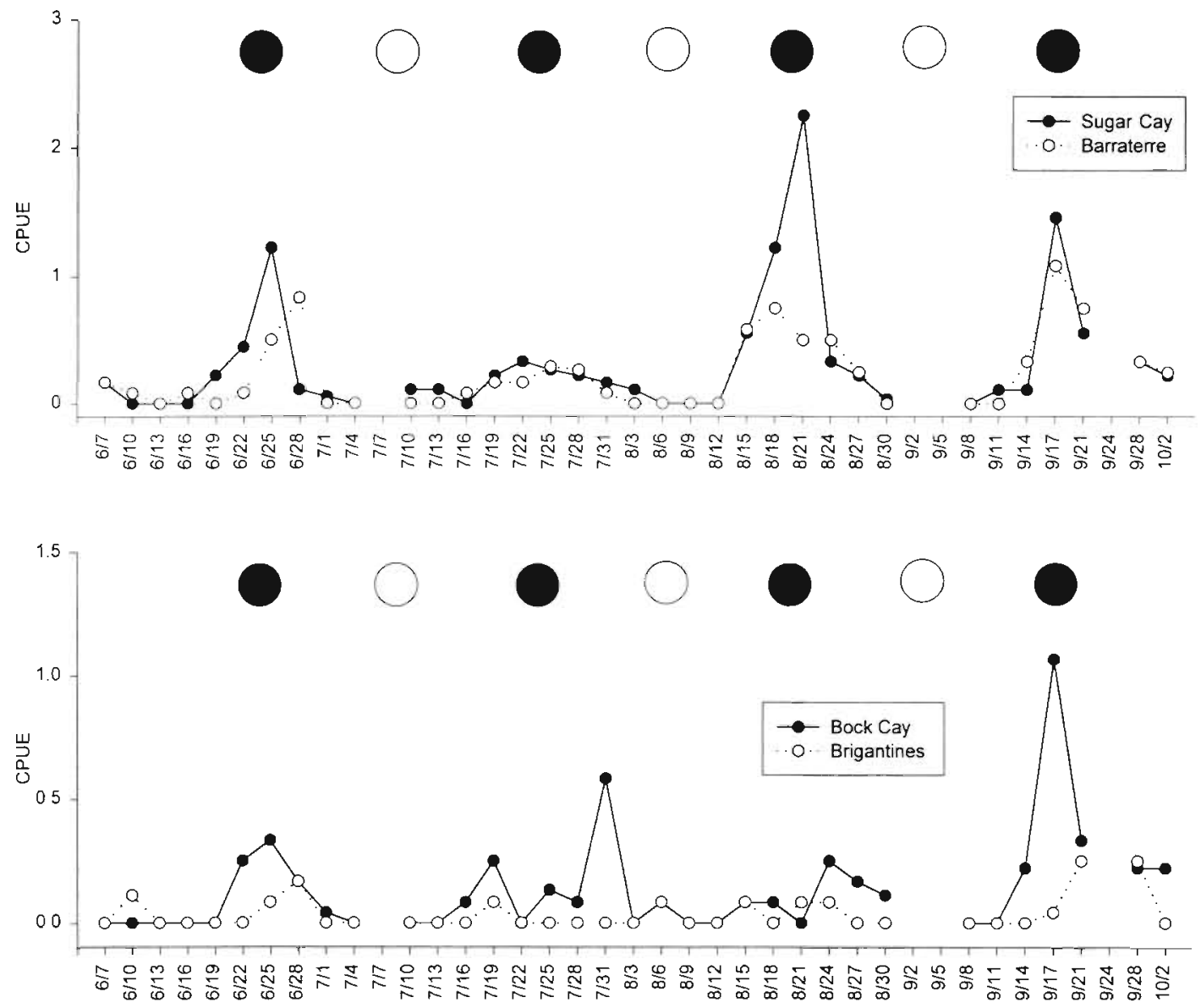

Fig. 2. Lunar periodicity in mean CPUE (postlarvae substrate $\mathrm{e}^{-1} \mathrm{~d}^{-1}$ ) of Panulirus argus pueruli at 4 sites within the vicinity of Lee Stocking Island, Bahamas. Each data point represents the mean of 4 to 8 substrates; error bars are not included to maintain clarity. See Table 1 for significance levels. Dates given as mo/d

$1,14 ; \mathrm{p}=0.08)$. In all cases, a first-order autoregression function reduced the residuals to white noise (chisquared test: $\mathrm{p}>0.05$; Durbin-Watson test: $W=2.09$ ). The residuals were distributed normally (Shapiro-Wilk test: all $p>0.05$ ).

\section{Spatiotemporal variation and environmental control of settlement}

Spatial patterns

Mean postlarval settlement pooled across years varied significantly by site ( 1 -way ANOVA: $F=22.28$; $\mathrm{df}=$ 7,$349 ; \mathrm{p}=0.0001$ ). Settlement was significantly higher at BB1, BB2 and SC than at the other 5 sites (Ryan's $Q$ tests; Fig. 5). There was strong spatial coherence in settlement of pueruli among nearly all sites sampled (Table 2). Cross-correlation analyses revealed significant leads and lags ranging from -12 to 12 mo for various time series (Table 2). Settlement at SC was signifi- cantly cross-correlated with settlement at 3 sites in nearby Barraterre Bay (BB1, BB2, BB4), as well as NP (Table 2, Fig. 1). All sites within Barraterre Bay (BB1, $\mathrm{BB} 2, \mathrm{BB} 4)$ were significantly correlated with each other (Table 2). Site BB3 was eliminated from crosscorrelation analyses because prior 'pre-whitening' with ARIMA time-series models revealed non-stationarity in the data, despite numerous transformations. With the exception of the cross-correlation between $\mathrm{BB} 1$ and BRI, all sites north of Barraterre Bay (NP, $\mathrm{BOC}, \mathrm{BRI})$ were significantly correlated with settlement at Barraterre Bay (Table 2). Settlement at NP was significantly cross-correlated with settlement at all other sites except BOC (Table 2). Settlement at BOC was significantly cross-correlated with settlement at Barraterre Bay and BRI (Table 2). Thus, there appears to be relatively strong spatial coherence in settlement of Panulirus argus pueruli at both local (10s of $\mathrm{m}, \mathrm{km}$ ) and regional (10s of $\mathrm{km})$ spatial scales. Moreover, BB1 and BB2 appear to be the best indicators of settlement for the region surrounding LSI. 


\section{Temporal patterns}

We chose to describe annual and seasonal variation in settlement, as well as the effects of environmental variables on settlement, at SC, BB1, and BB2 (see below) because these sites exhibited the highest settlement and longest time series of all sites examined (see section above; Fig. 5). Mean annual settlement of pueruli pooled across $\mathrm{SC}, \mathrm{BB} 1$ and $\mathrm{BB} 2$ did not vary significantly between years over a $5 \mathrm{yr}$ period (1-way ANOVA; $F=0.68 ; \mathrm{df}=5,58 ; \mathrm{p}=0.64 ;$ Fig. 6), despite adequate statistical power ( 0.80). Mean CPUE at SC, $B B 1$, and BB2 showed strong seasonality, with peak settlement in the fall of each of 6 years (Fig. 7). The fall settlement peak was relatively high and well-defined within a 3 mo window (September to November) at BB1 and BB2 (Fig. 7), whereas the fall settlement peak at $\mathrm{SC}$ was relatively low and had greater variation in

Plankton Nets vs. Surface Substrates Site BB1

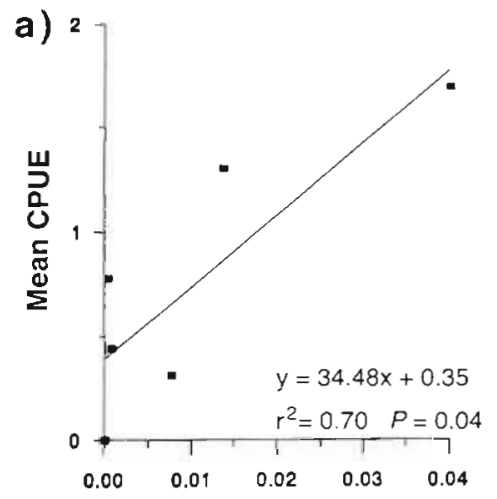

Pueruli Concentration (no. $/ \mathrm{m}^{3}$ )

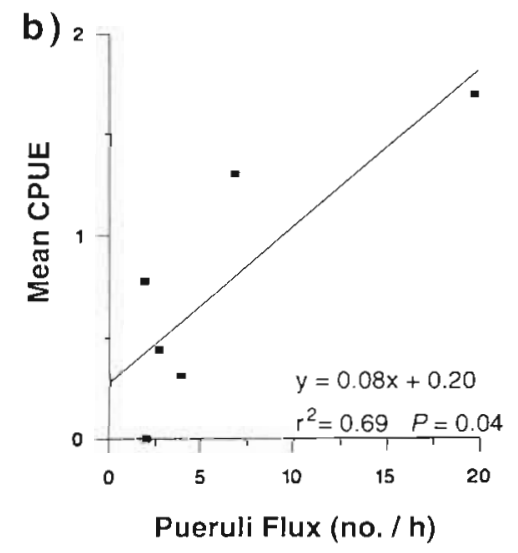

Plankton Nets vs. Surface Substrates Site BB2

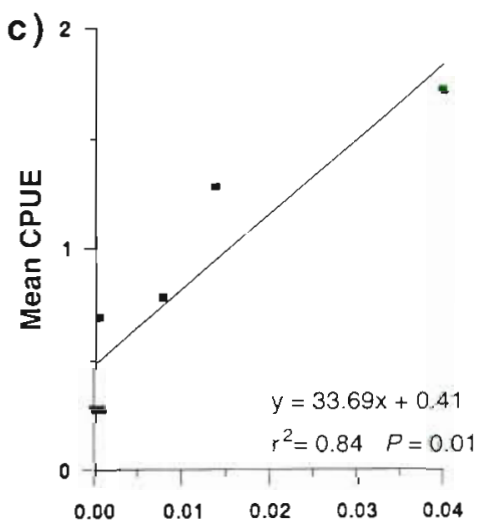

Pueruli Concentration (no. $/ \mathrm{m}^{3}$ ) both magnitude and timing (August to November) (Fig. 7). Peak settlement varied 1 - to 4 -fold between years within a given site (Fig. 7).

\section{Relationship between pueruli anomalies and environmental variables}

During the 5 yr study period in which environmental variables were recorded, winds were highly variable in speed and direction (Figs. 8 to 12). Wind speeds ranged from $0 \mathrm{~m} \mathrm{~s}^{-1}$ during calm weather conditions to $7 \mathrm{~m} \mathrm{~s}^{-1}$ during the passage of cold fronts or tropical cyclones. Winds were particularly variable during the fall and winter months (Julian Days 300-90), when relatively calm southeasterly winds (blowing towards the northwest) were punctuated by strong northeasterly winds (blowing towards the southwest) in association with the passage of cold fronts (Figs. 8 to 12). Northeasterly winds associated with cold fronts apparently trigger nearshore currents to shift direction from flowing northwestward to flowing across the shelf and eventually southeastward (Shenker et al. 1993). Windinduced shifts in the prevailing direction of nearshore currents can take place within several days (Shenker et al. 1993). The spring and summer months (Julian Days 120-240) were characterized by relatively steady and moderate offshore winds (Figs. 8 to 12). In 1990 at Sugar Cay Bay, relatively strong, positive pueruli anomalies (PL anomalies) occurred on Julian Days 179-180 and 234-237 and corresponded with strong alongshore winds $\left(-4\right.$ to $\left.5 \mathrm{~m} \mathrm{~s}^{-1}\right)$ blowing towards the southeast (Fig 8). Similarly, a strong positive $\mathrm{PL}$ anomaly at site BB1 on $\mathrm{Ju}$ lian Days 280-285 corresponded to along-shore winds blowing towards the southeast (Fig , 8). Relatively strong negative PL anomalies at BB1 on Julian Days 245-248 and 274-278 also corresponded to along-shore winds blowing towards the southeast; however, a rela tively strong offshore component to wind stress during these periods may have hindered onshore transport of pueruli (Fig. 8). In 1991, a relatively strong positive PL anomaly around Julian Day 309 occurred at all 3 sites and followed the passage of a cold front, which produced strong along-shore

Fig. 3. Relationship between mean CPUE as measured with floating, modified 'Witham-type' artificial substrates, and density of pueruli in the water column as measured with plankton nets (pueruli concentration: $a, c ;$ pueruli flux: $b, d$ ) at Barraterre Bay sites BB1 $(a, b)$ and BB2 (c, d) 


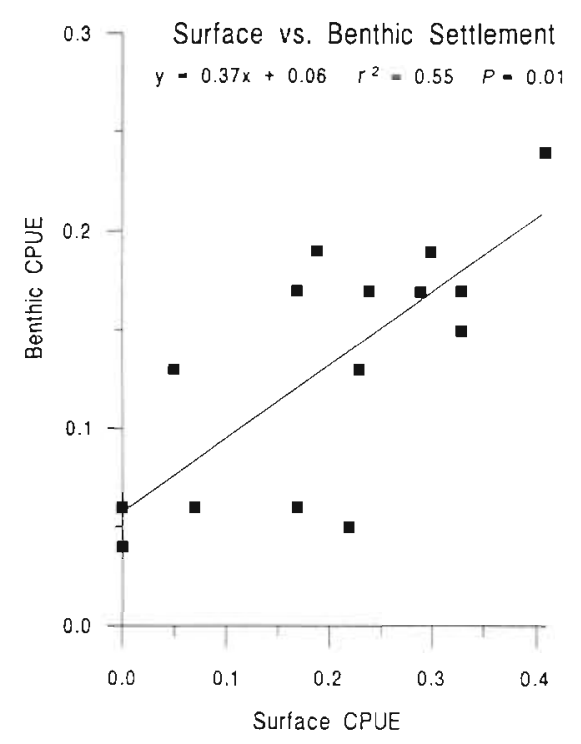

Fig. 4. Relationship between mean surface and benthic CPUE at Sugar Cay Bay

winds ( $4 \mathrm{~m} \mathrm{~s}^{-1}$ ) blowing towards the southeast (Fig. 9). In 1991, there were relatively strong, negative $\mathrm{PL}$ anomalies on Julian Days 220, 250 and 280, which corresponded to weak along-shore winds and relatively strong (4 $\left.\mathrm{m} \mathrm{s}^{-1}\right)$ offshore winds (Fig. 9). During 1992, most of the PL anomalies were relatively small at 3 sites, and were nearly always negative at Sugar Cay Bay (Fig. 10). Relatively high PL anomalies were observed at sites BB1 and BB2 around Julian Days 210 and 265 , and corresponded to relatively strong winds blowing towards the southeast (Fig. 10). Similarly, 2 relatively strong, positive PL anomalies occurred around Julian Days 53 and 280 at all sites in 1993, and corresponded to strong winds blowing towards the southeast (Fig. 11). In 1994, positive PL anomalies occurred

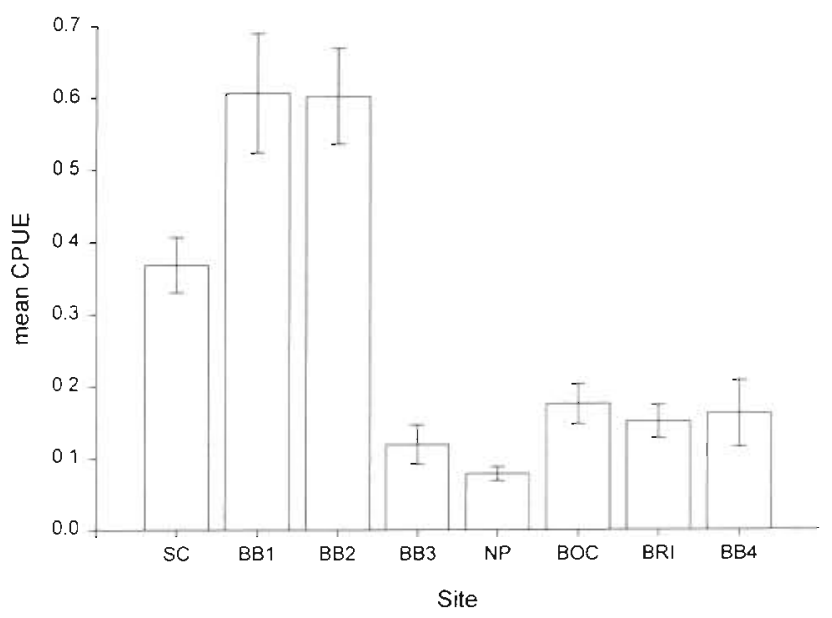

Fig. 5. Mean CPUE (pooled across time; 1990 to 1995 ) at sites within the vicinity of Lee Stocking Island, Bahamas. $n=16$ to 64 per site. See legend of Fig. 1 for site abbreviations. Graph shows back-transformed mean $\pm 1 \mathrm{SE}$

around Julian Days 22, 100, 250 and 340 at all 3 sites, and corresponded to strong winds blowing towards the southeast (Fig. 12). Thus, in general, relatively strong along-shore winds blowing towards the southeast during peak recruitment during the fall (Julian Days 270-330) corresponded with positive PL anomalies (Figs. 8 to 12). Positive PL anomalies occurred during both onshore and offshore components of wind stress (Figs. 8 to 12).

Time-series analyses of PL anomalies and wind stress identified positive and significant cross-correlations between settlement and along-shore components of wind stress, but not cross-shelf components of wind stress. In all cases, first-order autoregressive models reduced the 5 yr time series of PL anomaly to white noise (chi-squared test: all $\mathrm{p}>0.05$; Durbin-Watson

Table 2. Results of cross-correlation analyses of 'pre-whitened' monthly mean CPUE data between 7 sites near Lee Stocking Island, Bahamas (see legend of Fig. 1 for site abbreviations). Site BB3 was not included in this summary because of non-stationarity in the data (i.e. the autocovariance sequence was not a positive definite). Shown are significant monthly leads or lags for each time series. The leads or lags are listed in decreasing order of significance. Significant values are all positively cross-correlated; there were no significant negative correlations. See the legend of Fig. 1 for site abbreviations. Despite the use of differencing and various orders of ARIMA models, significant autocorrelation remained in the SC time series at a lag of 6 mo; therefore all significant 6 mo lags were deemed spurious and eliminated. na: not applicable because the time series did not overlap ns: not significant

\begin{tabular}{|c|c|c|c|c|c|c|c|}
\hline & $\mathrm{SC}$ & BB1 & BB2 & BB4 & BRI & NP & $\mathrm{BOC}$ \\
\hline $\mathrm{SC}$ & - & $0,2,-11,-12$ & $0,2,12,-11,-12$ & $1,0,12$ & ns & $-11,0,1,2$ & ns \\
\hline BB1 & & - & $0,-5$ & 0,12 & ns & $-6,-4,-1,0,1$ & $12,11,0,-1,-6$ \\
\hline BB2 & & & - & 0,4 & $0,1,11,12,-11$ & 0 & $0,4,5,-10,-9,11,12$ \\
\hline BB4 & & & & - & na & $-1,0$ & 9,7 \\
\hline BRI & & & & & - & -1 & $12,0,2$ \\
\hline NP & & & & & & - & ns \\
\hline $\mathrm{BOC}$ & & & & & & & - \\
\hline
\end{tabular}




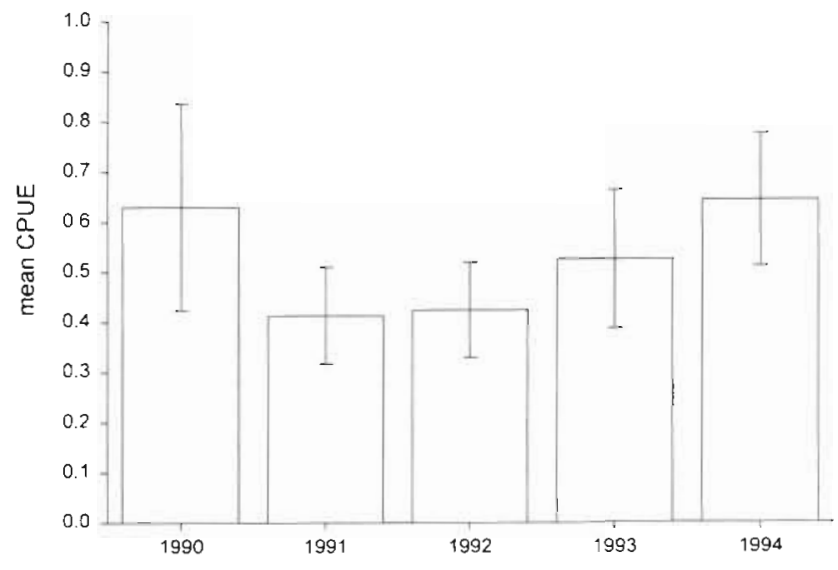

Fig. 6. Mean annual CPUE ( $\pm 1 \mathrm{SE}$ ) pooled across the 3 sites (SC, BB1, BB2) within the vicinity of Lee Stocking Island, Bahamas. $N=6$ to $8 \mathrm{yr}^{-1}$ See legend of Fig. 1 for site abbreviations

test: all $W>1.88)$; the residuals were distributed normally (Shapiro-Wilk test: all $\mathrm{p}>0.89$ ). At $\mathrm{SC}$, there was a positive and significant relationship between PL anomaly and along-shore wind speed blowing towards the southeast with a lead of 4 to $5 \mathrm{~d}$ ( $t$-test: $p<0.02$ ). This analysis accounted for $\sim 45 \%$ of the variation in the PL anomaly time series. At BB1, there was a positive and significant relationship between PL anomaly and southeastward along-shore wind speed at leads of $+5,+1$, and $0 \mathrm{~d}(t$-test: all $\mathrm{p}<0.04)$, which accounted for $\sim 53 \%$ of the variation in the PL anomaly time series. Similarly, at BB2 there was a positive and significant relationship between PL anomaly and southeastward along-shore wind speed at leads of $+4,+3$, +1 , and $0 \mathrm{~d}$ ( $t$-test: all $\mathrm{p}<0.05$ ). This analysis accounted for $\sim 66 \%$ of the variation in the PL anomaly time series at BB2. Thus, there was a significant relationship between along-shore wind speed and PL anomaly at all 3 sites (SC, BB1, BB2), though approximately half of the variation ( 44 to $55 \%$ ) was unexplained by wind speed and direction alone.

Water temperature ranges were similar across years and followed quasi-steady seasonal heating and cooling, with highest temperatures recorded during July-August $\left(\sim 30^{\circ} \mathrm{C}\right)$ and lowest temperatures recorded during January-February $\left(\sim 24^{\circ} \mathrm{C}\right)$. There was no significant cross-correlation between the PL anomaly and water temperature for any of the sites examined (SC, BB1, BB2) (all $\mathrm{p}>0.46)$.

\section{DISCUSSION}

The region surrounding Lee Stocking Island, Bahamas, is an ideal site for examining spatiotemporal
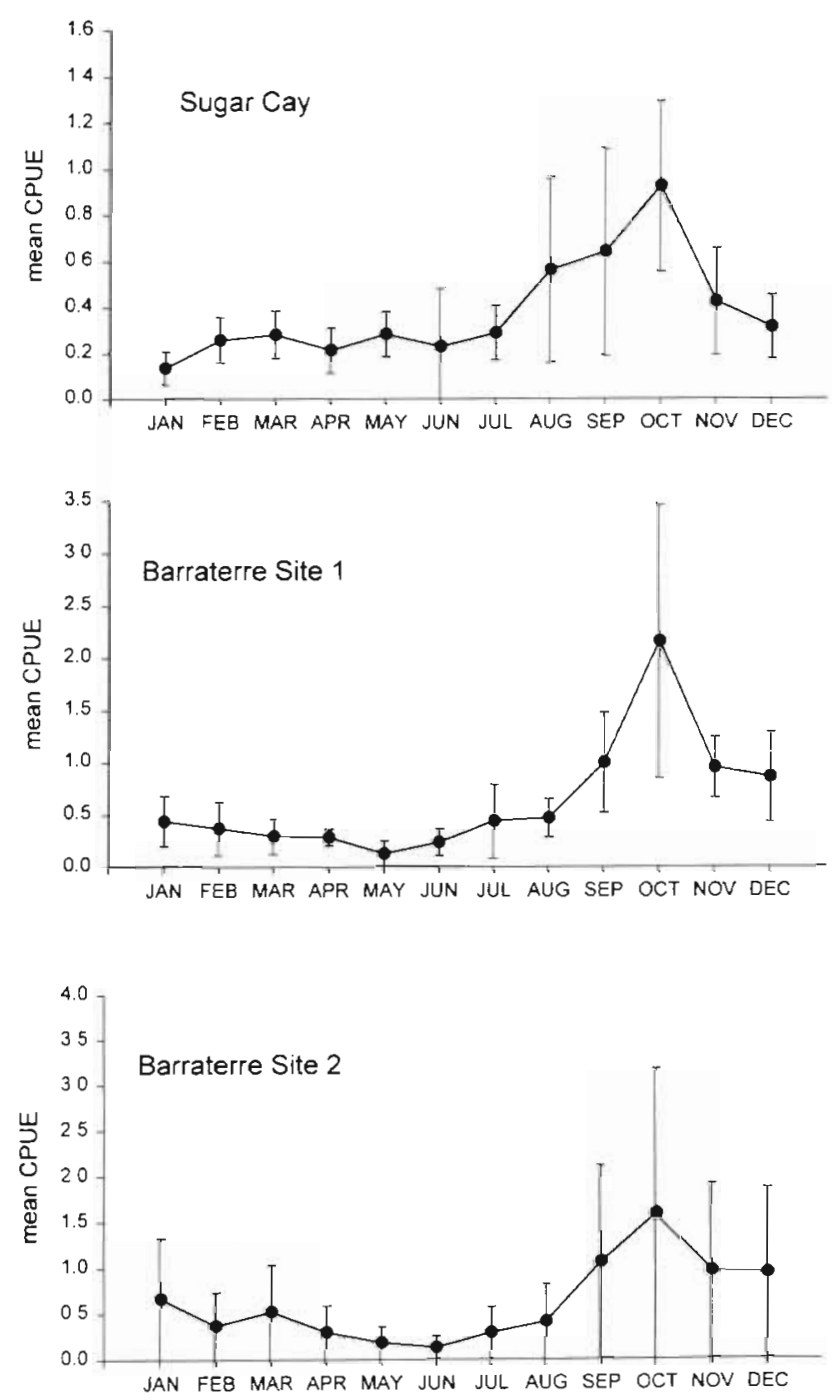

Fig. 7. Mean annual CPUE ( $\pm 1 \mathrm{SE}$ ) at Sugar Cay Bay and Barraterre Bay (Sites BB1 and BB2) from February 1990 to April 1995. $N=4$ to 8 surface substrates per site per month $x$

7 months. Note the differences in the scales of the $y$-axes

variation in postlarval settlement of Caribbean spiny lobster because of the close proximity of the pelagic realm to shallow nursery habitats. Consequently, onshore larval transport processes are not complicated by the extensive shelf areas and complex hydrographic features which are characteristic of other regions. The key findings from our study of settlement patterns, using standardized techniques, were that (1) significant lunar (first quarter of lunar phase) and seasonal (fall peak) periodicities in settlement were consistent across sites; (2) postlarval settlement varied more across sites $(-600 \%)$ than between years at a single site $(\sim 50 \%)$ and inter-site differences were consistent 
1990
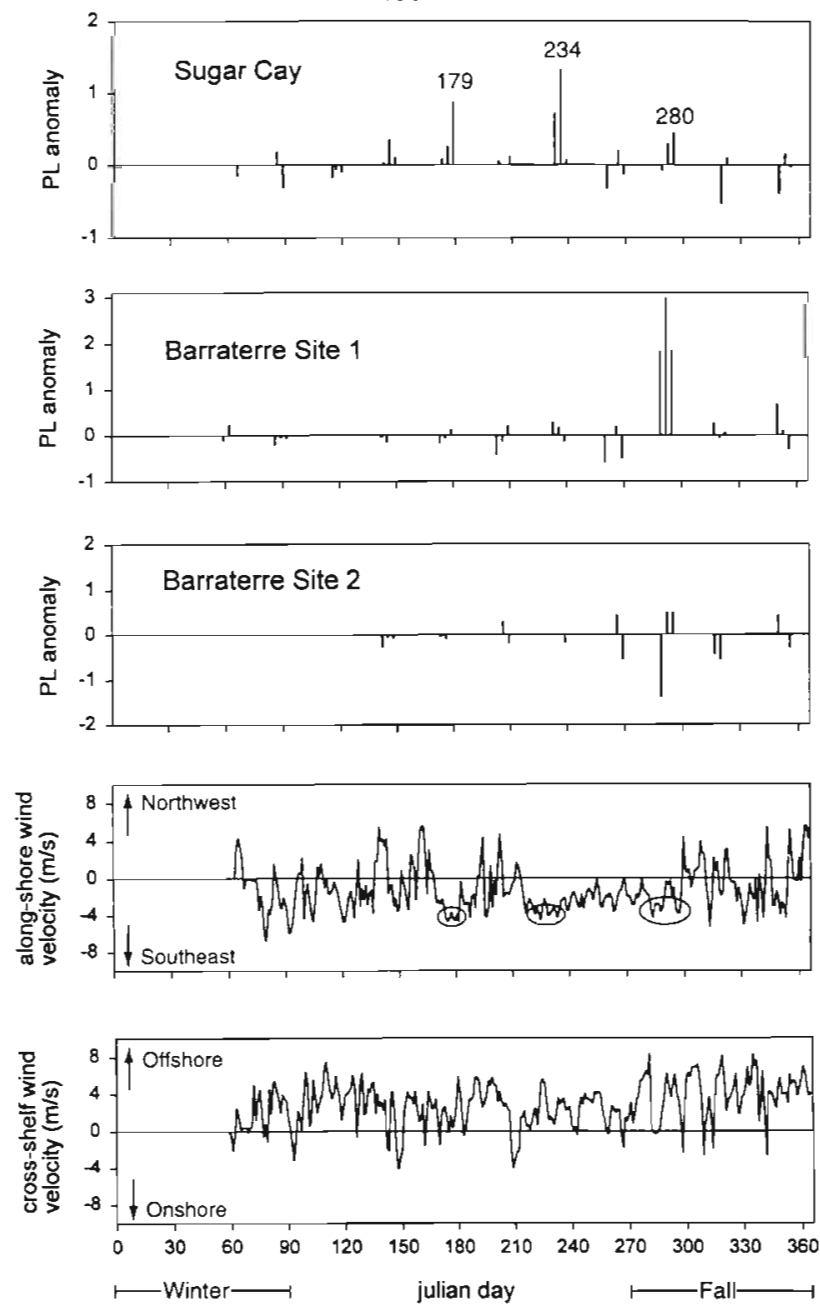

Fig. 8. Time series of pueruli anomaly ('PL anomaly' using anomalies from the monthly, 6 yr means to remove seasonal periodicity in the data) at sites in Sugar Cay and Barraterre Bays (SC, BB1 and BB2), and along-shore and cross-shelf components of wind velocity as measured at Lee Stocking Island, Bahamas, during 1990. The wind data in 1990 were unavailable until Julian Day 60. Numbers above certain PL anomalies denote specific Julian Dâys. Circles around peaks of along-shore wind velocity denote certain wind events

across time (i.e. some sites always had higher settlement than others); (3) settlement was correlated with along-shore winds blowing towards the southeast, but not with cross-shelf winds or water temperature; (4) floating, 'Witham-type' artificial settlement substrates yielded an accurate index of postlarval concentration and flux past a given point; and (5) floating substrates were a relatively poor indicator of benthic settlement, though the relationship between surface and benthic settlement may depend upon benthic habitat availability and postlarval supply.
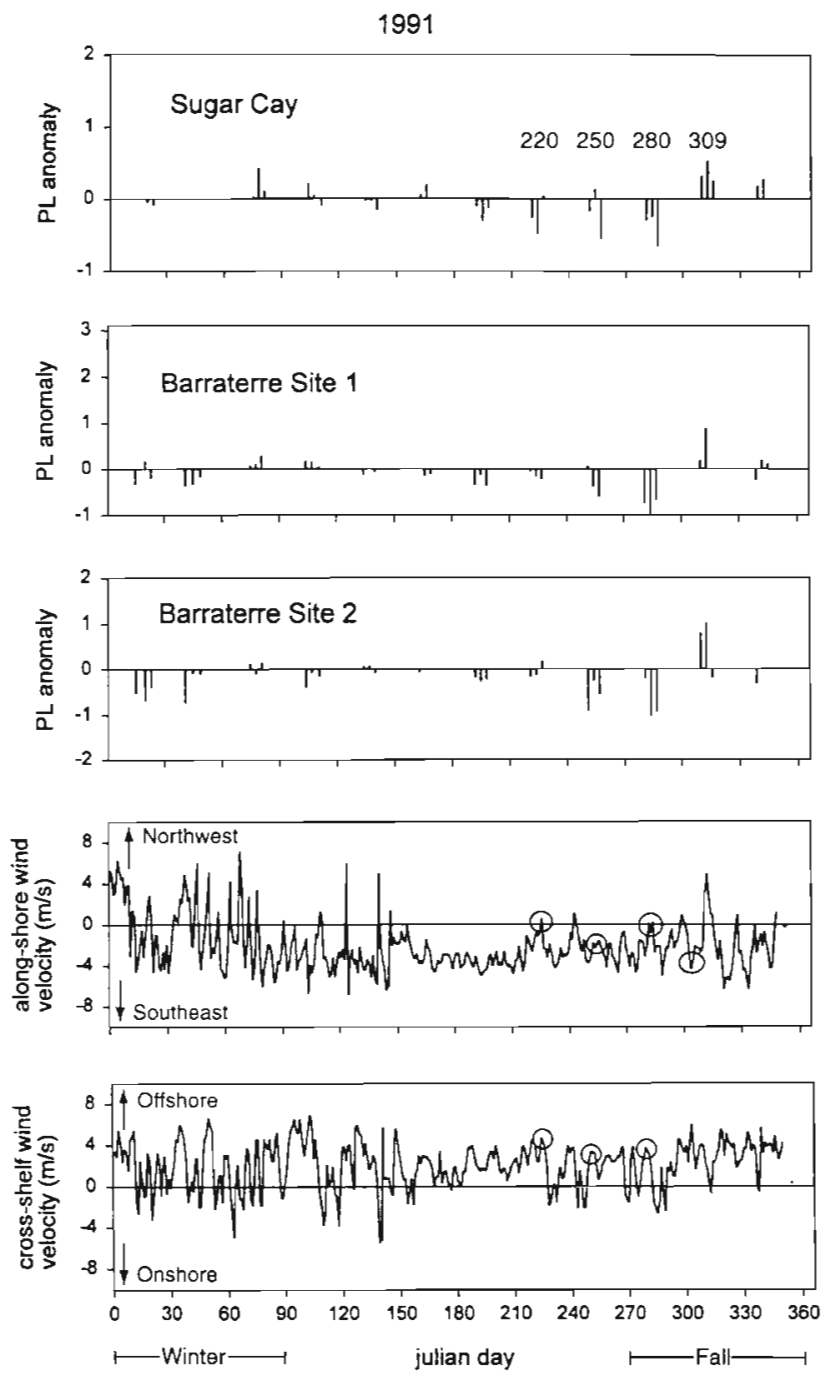

Fig. 9. Time series of pueruli anomaly at sites in Sugar Cay and Barraterre Bays, and along-shore and cross-shelf components of wind velocity measured at Lee Stocking lsland, Bahamas, during 1991. Numbers above certain PL anomalies denote specific Julian Days. Circles around peaks of alongshore and cross-shelf wind velocity denote certain wind events

\section{Relevance of data obtained from artificial settlement substrates}

Research on postlarval recruitment dynamics of commercially important custacean species such as the blue crab Callinectes sapidus, Western Australian rock lobster Panulirus cygnus, and Caribbean spiny lobster Panulirus argus typically employs floating, artificial settlement substrates (Phillips \& Booth 1994, van Montfrans et al. 1995, Acosta et al. 1997 and references therein). Nevertheless, information with which to gauge the relevance of such data to actual postlarval concentrations in the water column, to benthic settle- 
1992
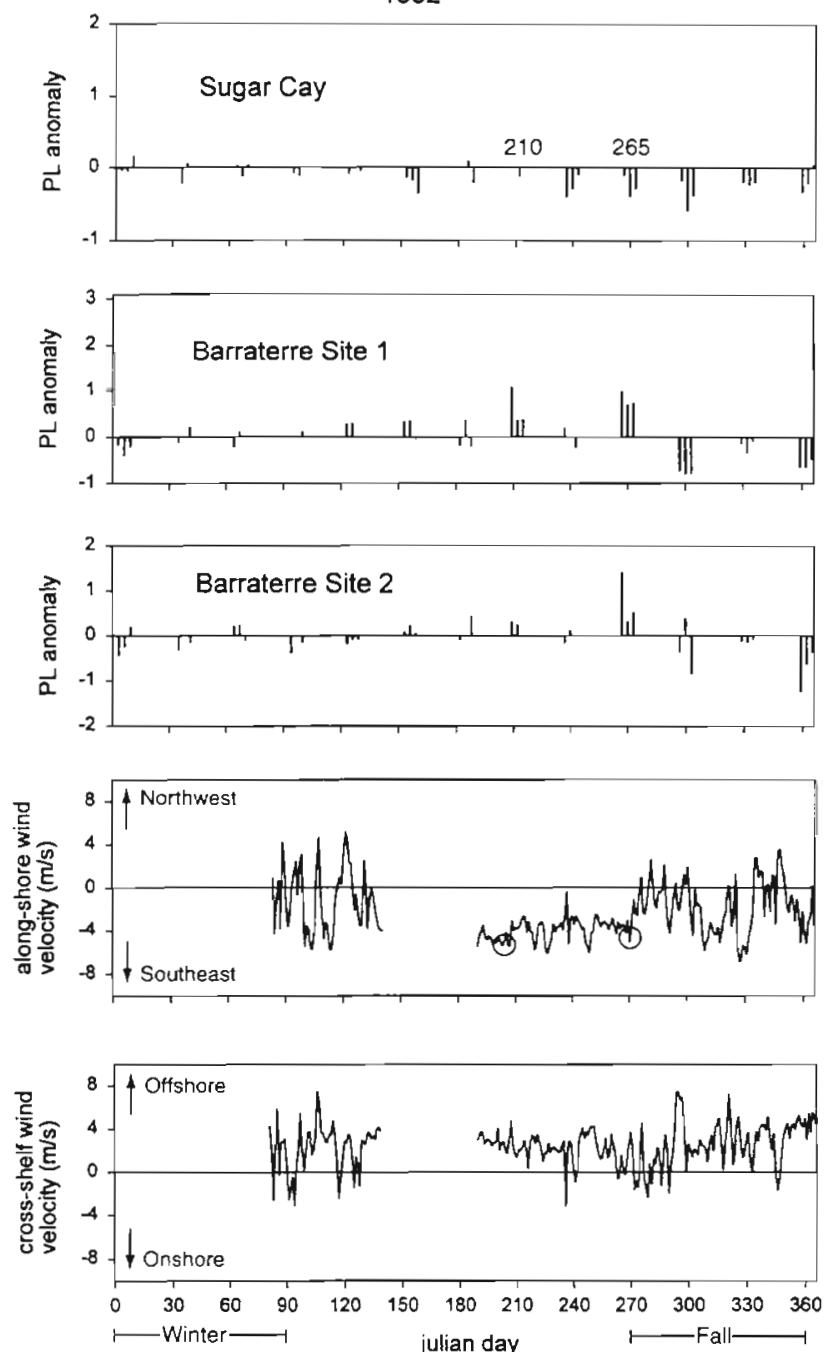

Fig. 10. Time series of pueruli anomaly at sites in Sugar Cay and Barraterre Bays, and along-shore and cross-shelf components of wind velocity measured at Lee Stocking Island, Bahamas, during 1992. Wind data are missing during Julian Days 0 to 70 and 140 to 190 because the weather station was not operating. Numbers above certain PL anomalies denote specific Julian Days. Circles around peaks of along-shore wind velocity denote certain wind events

ment, and to juvenile or adult abundance is scant (but see Butler \& Herrnkind 1992, Phillips \& Booth 1994, Coba-Cetina 1995, Eggleston \& Armstrong 1995, Metcalf et al. 1995). Our results suggest that settlement on modified, 'Witham-type' substrates deployed in a mangrove-fringed, macroalga-dominated nursery area yields an accurate index of the concentration (no. $\mathrm{m}^{-3}$ ) and flux (no. $\mathrm{h}^{-1}$ ) of pueruli entering the area, thereby providing an efficient technique for comparing postlarval influx between regions. These results are consistent with a similar study conducted in Barraterre Bay, but using data generated on a daily basis within a sin-
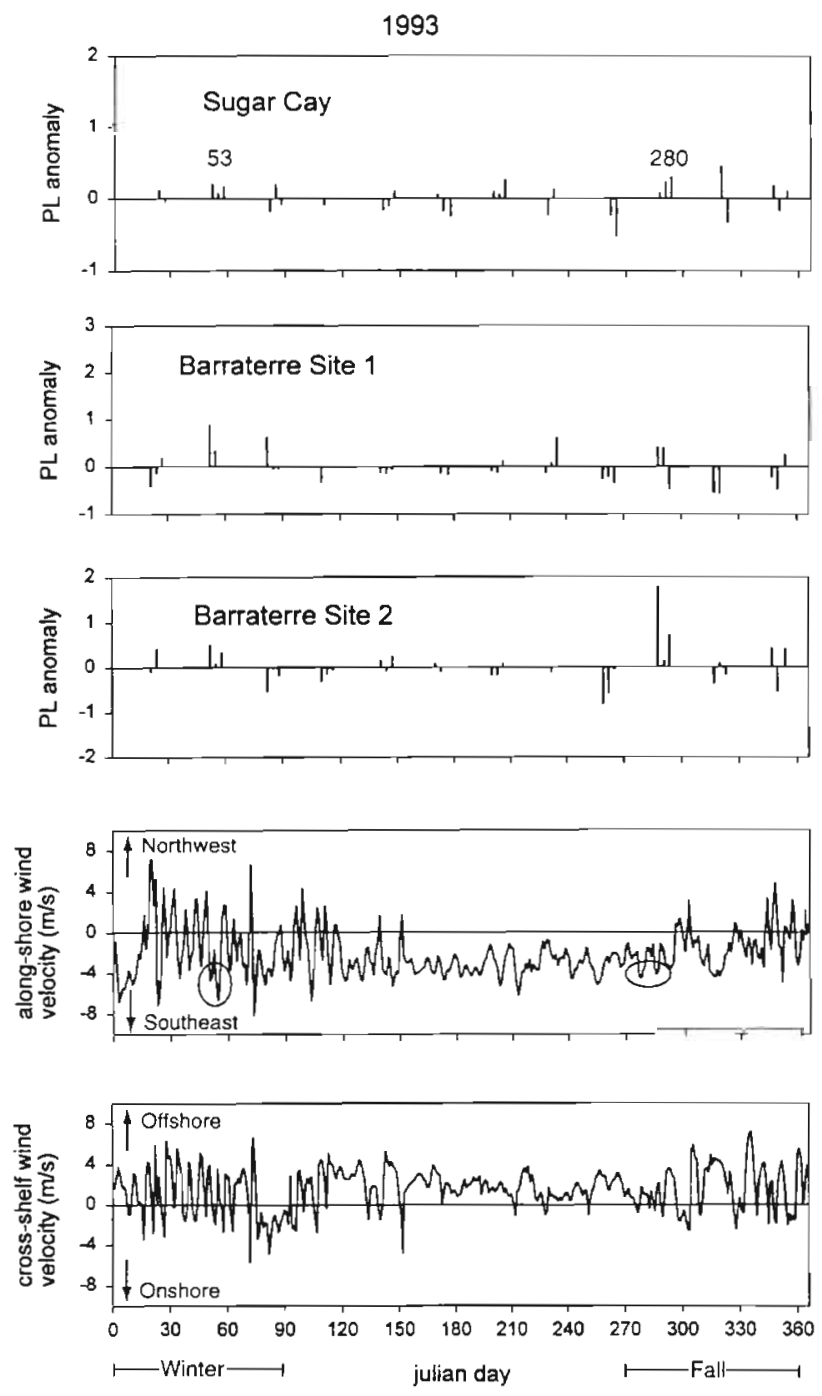

Fig. 11. Time series of pueruli anomaly at sites in Sugar Cay and Barraterre Bays, and along-shore and cross-shelf components of wind velocity measured at Lee Stocking Island, Bahamas, during 1993. Numbers above certain PL anomalies demote specific Julian Days. Circles around peaks of alongshore wind velocity denote certain wind events

gle month, in which settlement of pueruli on surface 'Witham' substrates was positively and significantly correlated with planktonic concentrations as measured. with plankton nets (Coba-Cetina 1995). Similarly, Butler \& Herrnkind (1992) found a positive correlation between settlement on modified 'Witham' substrates offshore of the Florida Keys, USA, and concentrations of pueruli; however, the trend in their study was not significant.

The relationship between surface and benthic settlement was much more variable than that between postlarval supply and settlement. For example, there was a positive and significant relationship between surface and benthic settlement at only 1 of our 3 sites (Sugar 
1994
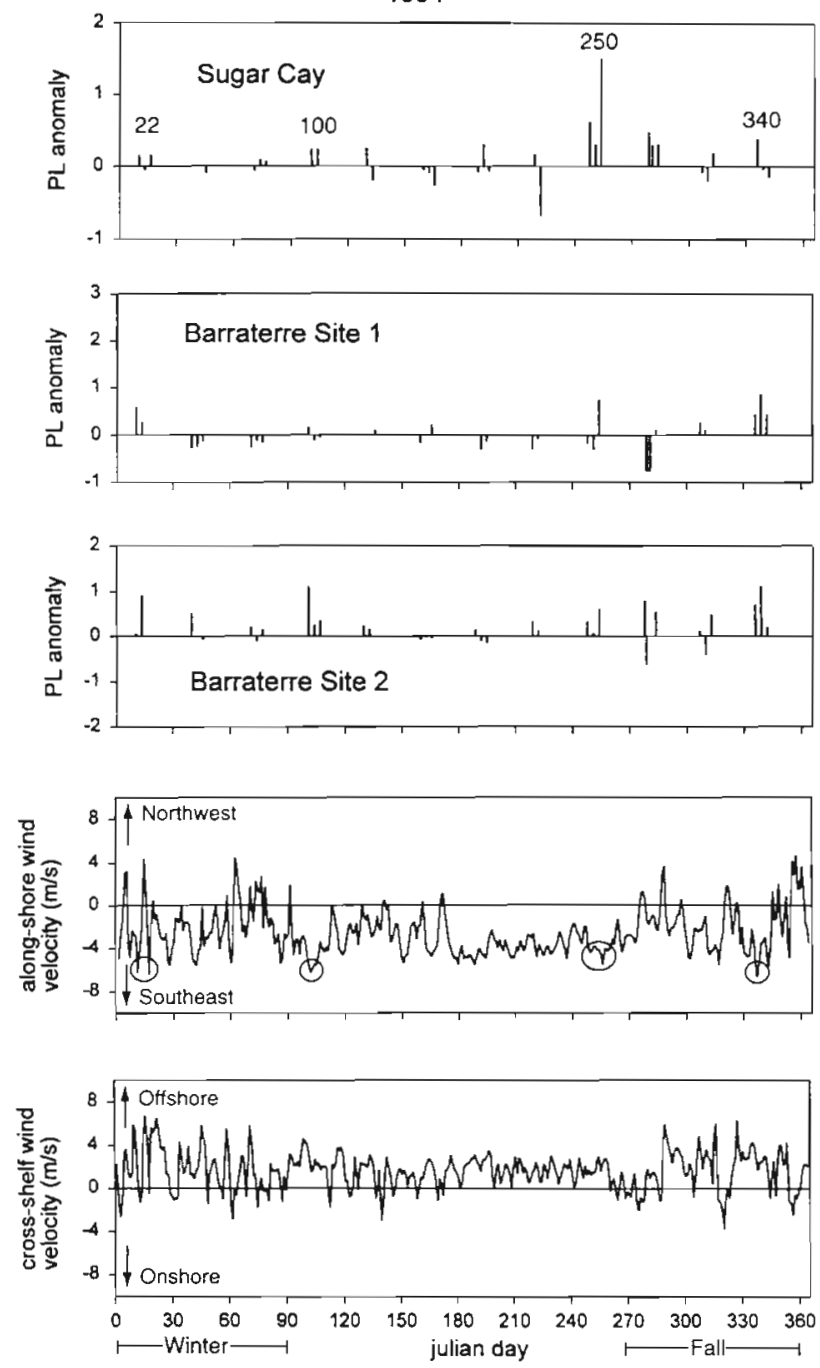

Fig. 12. Time series of pueruli anomaly at sites in Sugar Cay and Barraterre Bays, and along-shore and cross-shelf components of wind velocity measured at Lee Stocking Island, Bahamas, during 1994. Numbers above certain PL anomalies denote specific Julian Days. Circles around peaks of along. shore wind velocity denote certain wind events

Cay vs Barraterre Bay and Norman's Pond). Sugar Cay contains a large, expansive seagrass meadow characterized by relatively high settlement of pueruli (see above). Barraterre Bay contains expansive macroalgal meadows and was characterized by high settlement, whereas Norman's Pond contains very sparse seagrass and was characterized by relatively low puerulus settlement (see above). Given that none of the habitat type and settlement conditions just described were replicated, nor experimental manipulations conducted (e.g. predator exclusion), it is unclear if settlement on surface and benthic substrates were decoupled due to ecological processes such as habitat- and densitydependent post-settlement predation and migration, habitat-dependent active substrate selection behavior, or some negative physical aspect of the benthic substrate itself. Similarly, there was no relationship between settlement of pueruli on artificial surface and benthic substrates in the Florida Keys (Butler \& Herrnkind 1992). Thus, we urge caution in extrapolating settlement patterns measured on artificial surface substrates to local benthic settlement patterns.

\section{Patterns and processes underlying spatiotemporal variation in settlement}

Lunar periodicity

The settlement peaks of pueruli between the newmoon and first quarter lunar phases observed in this study are characteristic of lunar periodicity in settlement patterns of Panulirus argus throughout the Caribbean and Florida, as well as several other species of palinurids (Marx 1986, Little \& Milano 1980, Ward 1989, Bannerot et al. 1991, Cruz et al. 1991, BrionesFourzan 1994, Lipcius \& Cobb 1994, Acosta et al. 1997). New-moon spring tides provide the potential for tidal transport due to increased water exchange between coastal waters and the Bahama Banks ( $N$. Smith, HBOI, unpubl. data), and because recruitment during the darkest phase of the lunar cycle could reduce susceptibility to visual predators (Acosta 1997). Many crustaceans and fish recruit to inshore nursery habitats during new-moon spring tides, including blue crabs (Mense et al. 1995, Wrona et al. 1995), caridean shrimp (Little \& Milano 1980), and various species of fish (Tanaka et al. 1989, Shenker et al. 1993, Thorrold et al. 1994, Mojica et al. 1995).

Scales of spatiotemporal variation in settlement

The manner in which our perception of ecological patterns and processes is influenced by the spatial and temporal scales of study is a fundamental issue in ecology (Kareiva 1987, Levin 1992, Gustafson \& Gardner 1996, Thrush et al. 1996, Eggleston et al. 1998a). Moreover, most field studies are restricted to relatively small spatial and short temporal scales because of funding and logistical constraints (Levin 1992). Our monthly measures of puerulus settlement on 32 to 48 standardized substrates, which were sampled for up to 6 yr and located at 8 sites spanning a longitudinal and onshore distance of $43 \mathrm{~km}$ and $11 \mathrm{~km}$, respectively, identified (1) significant differences in relative settlement between sites, yet some strong spatial coherence in settlement between sites over time, (2) pronounced and consistent lunar and seasonal variation in settle- 
ment, (3) relatively low annual variability in settlement when pooled across months within a year, and (4) settlement rates which were comparable to rates measured in Florida Bay, Bermuda, and the Caribbean (Marx 1986, Ward 1989, Bannerot et al. 1991, BrionesFourzan 1994).

There was a general decline in relative settlement intensity moving from seaward sites (e.g. Sugar Cay, Barraterre Bay) to inshore sites (Norman's Pond Cay, Brigantine Cays) (Fig. 1). This spatial settlement pattern is consistent with the notion of a 'recruitment shadow' (Roughgarden et al. 1988), whereby the most seaward sites enjoy high postlarval supply and settlement, and more inshore sites have lower postlarval supply and settlement either because postlarvae have settled out of the water column or the planktonic concentration of pueruli is diluted as waters from Exuma Sound mix with waters from the Bahama Banks. Although relative settlement intensity varied among our 8 sampling sites, temporal variation in the magnitude of settlement between sites was coherent. Thus, any mesoscale hydrographic features that may have led to spatial variation in postlarval supply appear to be operating at scales larger than $50 \mathrm{~km}$.

The results from a recent study of postlarval settlement in Exuma Sound suggest that spatial coherence may be decoupled at regional scales greater than $50 \mathrm{~km}$ (Lipcius et al. 1997). For example, during the falls of 1994 to 1996, we quantified settlement patterns of pueruli at 3 additional, geographically separate sites fringing Exuma Sound: (1) Cat Island (located $-75 \mathrm{~km}$ ENE of LSI), (2) Eleuthera (located $\sim 100 \mathrm{~km}$ NNE of LSI), and (3) the Exuma Cays Land \& Sea Park (ECLSP; located $\sim 75 \mathrm{~km}$ NNW of LSI) (Lipcius et al. 1997). Settlement of pueruli was highest at Cat Island, followed by LSI, with no difference in settlement rates between Eleuthera and the ECLSP (Lipcius et al. 1997). Circulation in Exuma Sound is dominated by single or twin, large-scale gyres (B. Hickey unpubl. data), which apparently concentrate larvae near their centers and advect postlarvae selectively over broad spatial scales (50 to $100 \mathrm{~km}$ ), especially towards Cat Island (Lipcius et al. 1997 this study). Thus, the collective evidence from this study and Lipcius et al. (1997), suggests that settlement is spatially coherent at scales $<50 \mathrm{~km}$, and spatially decoupled at scales $>50 \mathrm{~km}$, due to regional variation in hydrodynamic transport of pueruli.

The most distinct temporal variations in settlement pattems observed in this study were lunar periodicity at weekly scales (discussed above), seasonal variation at monthly scales, and episodic settlement peaks in association with along-shore wind events blowing from the northwest towards the southeast. Although spiny lobster postlarvae recruit to LSI year-round, our 6 yr time series at 3 sites indicated a consistent sea- sonal peak in settlement during the fall (September to November), which may reflect seasonal differences in current patterns that influence larval or postlarval retention and advection, as well as seasonal spawning. For example, the percentage of egg-bearing Panulirus argus near LSI peaks during June and subsequently declines throughout autumn (Herrnkind \& Lipcius 1989). An early summer peak in spawning activity in $P$. argus also occurs in the Dry Tortugas, USA (Davis 1977), Bermuda (Sutcliffe 1953) and the U.S. Virgin Islands (Olsen et al. 1975). An early summer peak in spawning does not correspond with a fall peak in settlement if one assumes a 9 mo larval duration (Lyons 1980). Thus, peak times of local spawning (June) do not appear to be strongly coupled to peak settlement (October) over time. Therefore, fall peaks in settlement of pueruli near LSI probably reflect a combination of current patterns that may advect larvae out of Exuma Sound during the spring and summer and into the sound during fall and winter (B. Hickey University of Washington, unpubi. data), and some local spawning during the spring.

At monthly to annual time scales, wind-induced along-shore transport had a significant effect on settlement of pueruli, particularly at sites located at Barraterre Bay, where settlement was generally high. Previous oceanographic collections and behavioral observations indicate that pueruli reside in surface waters (0 to $2 \mathrm{~m}$ depth; Calinski \& Lyons 1983, Yeung \& McGowan 1991, Heatwole et al. 1992). Such behavioral patterns, combined with the positive correlation between along-shore wind speed and settlement, suggest that wind-induced surface currents have a strong influence on transport of pueruli to near-shore nursery habitats, particularly during the fall, when numerous cold fronts generate favorable along-shore winds and concentrations of pueruli in the water column are seasonally high. Nevertheless, approximately $50 \%$ of the variance in PL anomalies in this study was not explained by the speed of along-shore winds. Similarly, over $70 \%$ of the variation in Panulirus argus settlement in Florida Bay was unexplained by windinduced transport and annual periodicities (Acosta et al. 1997). This unexplained variation could be due to a variety of biological and physical factors, including local and regional patchiness of pueruli, variable larval developmental rates and vertical migration behavior of Iarvae, regional-scale meterological influences on water-levels, and the strength of coastal upwelling and downwelling (Cronin \& Forward 1986, Yeung \& McGowan 1991, Caputi \& Brown 1993, Blanton et al. 1995, Shanks 1995).

Meteorological and hydrodynamic control of variability in postlarval supply is characteristic of numerous commercially and ecologically important crus- 
taceans and finfish, and often drives fluctuations in marine populations (Fechhelm \& Griffiths 1990, Yeung \& McGowan 1991, Polovina \& Mitchum 1992, Caputi \& Brown 1993, Shenker et al. 1993, Booth \& Phillips 1994, van Montfrans et al. 1995, Acosta et al. 1997. Higgins et al. 1997). The results from this study indicate that artificial settlement substrates provide a reliable index of postlarval supply to inshore nursery habitats, and that a combination of stochastic and deterministic forces influence recruitment over various scales of time and space. Although this long-term recruitment study identified significant periodic (lunar and seasonal) and stochastic variation in postlarval supply to inshore nursery habitats, the degree to which environmentally driven variation in postlarval supply interacts with density-dependent, post-settlement processes in explaining population dynamics of Caribbean spiny lobster in the central Bahamas remains to be examined.

Acknowledgements. We are especially grateful to L. CobaCetina, J. Chaves, Capt. P. 'Quibb' Gerdes, J. van Montfrans, D. Fuss, M. Seebo, D. Nadeau, B. Patton, A. Adams and W. Stockhausen for field assistance. Tremendous logistical support was provided by the staff of the Caribbean Marine Research Center, as well as the Crustacean Ecology program at the Virginia Institute of Marine Science. We also thank D. Dickey for statistical advice on time-series analyses, and $T$ McKellar for producing some of the figures. The manuscript was improved by thoughtful comments by $\mathrm{M}$. Butler and 4 anonymous referees. This work was funded by the Caribbean Marine Research Center, National Undersea Research Center of the National Oceanic and Atmospheric Administration; the College of William and Mary; and North Carolina State University. This paper is dedicated to the memory of Ben Blaylock

\section{LITERATURE CITED}

Acosta CA (1997) Ecology and early life history of the Caribbean spiny lobster, Panulirus argus: recruitment, predation, and habitat requirements. PhD dissertation, Old Dominion University, Norfolk, VA

Acosta CA, Matthews TR, Butler MJ IV (1997) Temporal patterns and transport processes in recruitment of spiny lobster (Panulirus argus) postlarvae to south Florida. Mar Biol 129:79-85

Bannerot SP, Ryther JH, Clark M (1991) Large-scale assessment of recruitment of postlarval spiny lobsters, Panulirus argus, to Antigua, West Indies. Proc Gulf Caribb Fish Inst 41:471-486

Berrill M (1975) Gregarious behavior of juveniles of the spiny lobster, Panulirus argus (Crustacea: Decapoda). Bull Mar Sci 25:515-522

Bertness MD, Gaines SD, Stephens EG, Yund PO (1992) Components of recruitment in populations of the acorn barnacle Semibalanus balanoides (Linnaeus). J Exp Mar Biol Ecol 156:199-215

Blanton J, Wenner E, Werner F, Knot D (1995) Effects of windgenerated coastal currents on the transport of blue crab megalopae on a shallow continental shelf. Bull Mar Sci 57: $739-752$

Bohnsack JA, Harper DE, McClellan DB (1994) Fisheries trends from Monroe County, Florida. Bull Mar Sci 54:982-1018
Booth JD, Phillips BF (1994) Early life history of spiny lobster Crustaceana 66:271--294

Briones-Fourzan P (1994) Variability in postlarval recruitment of the spiny lobster, Panulirus argus (Latreille, 1804) to the Mexican Caribbean coast. Crustaceana 66:326-340

Butler MJ IV, Herrnkind WF (1992) Spiny lobster recruitment in South Florida: quantitative experiments and management implications. Proc Gulf Caribb Fish Inst 41:508-515

Caddy JF, Gulland JA (1983) Historical patterns of fish stocks. Marine Policy, October, p 267-278

Caley MJ, Carr MH, Hixon MA, Hughes TP, Jones GP, Menge BA (1996) Recruitment and the local dynamics of open marine populations. Annu Rev Ecol Syst 27:477-500

Calinsky MD, Lyons WG (1983) Swimming behavior of the puerulus of the spiny lobster Panulirus argus (Latreille, 1804) (Crustacea: Palinuridae). J Crustac Biol 3:329-335

Caputi N, Brown RS (1993) The effect of environment on puerulus settlement of the western rock lobster (Panulirus cygnus) in Western Australia. Fish Oceanogr 2:1-10

Coba-Cetina L (1995) Immigration variability and post-settlement processes of the spiny lobster Panulirus argus in the Exuma Cays, Bahamas. MA thesis, The College of William and Mary, Williamsburg, VA

Colin PL (1995) Surface currents in Exuma Sound, Bahamas and adjacent areas with reference to potential larval transport. Bull Mar Sci 56:48-57

Connell JH (1985) The consequences of variation in initial settlement vs. post-settlement mortality in rocky intertidal communities. J Exp Mar Biol Ecol 93:11-45

Cronin TW, Forward RB (1986) Vertical migration cycles of crab larvae and their role in larval dispersal. Bull Mar Sci 39:192-201

Cruz R, deLeon ME, Diaz E, Brito R, Puga R (1991) Recruitamiento de puerulos de langosta (Panulirus argus) a la platforma Cubana. Rev Invest Mar 12:66-75

Davis GE (1977) Effects of recreational harvest on a spiny lobster, Panulirus argus population. Bull Mar Sci 27; 223-236

Day RW, Quinn GP (1989) Comparisons of treatments after an analysis of variance in ecology. Ecol Monogr 59:433-463

Eggleston DB (1995) Recruitment in Nassau grouper Epinephelus striatus: post-settlement abundance, microhabitat features, and ontogenetic habitat shifts. Mar Ecol Prog Ser 124:9-22

Eggleston DB, Armstrong DA (1995) Pre- and post-settlement determinants of estuarine Dungeness crab recruitment. Ecol Monogr 65:191-254

Eggleston DB, Etherington LL, Elis WE (1998a) Organism response to habitat patchiness: species and habitatdependent recruitment of decapod crustaceans. J Exp Mar Biol Ecol 223:11.-132

Eggleston DB, Grover JJ, Lipcius RN (1998b) Ontogenetic diet shifts in Nassau grouper trophic linkages and predatory impact. Bull Mar Sci 62: in press

Eggleston DB, Lipcius RN, Grover JJ (1997) Predator and shelter-size effects on coral reef fish and spiny lobster prey. Mar Ecol Prog Ser 149:43-59

Fechhelm RG, Griffiths WB (1990) Effect of wind on the recruitment of Canadian Arctic cisco (Coregonus autumnalis) into the central Alaskan Beaufort Sea. Can J Fish Aquat Sci 47:2164-2171

Fogarty MJ, Sissenwine MP, Cohen EB (1991) Recruitment variability and the dynamics of exploited marine populations. Trends Ecol Evol 6:241-246

Forcucci D, Butler MJ IV, Hunt JH (1994) Population dynamics of juvenile Caribbean spiny lobster, Panulirus argus in Florida Bay, FL. Bull Mar Sci 54:805-818 
Gaines SD, Brown S, Roughgarden J (1985) Spatial variation in larval concentration as a cause of spatial variation in settlement for the barnacle Balanus glandula. Oecologia $67: 26 ; .272$

Gilnes SD, Roughgarden J (1985) Larval settlement rate: a leading determinant of structure in an ecological community of the marine intertidal zone. Proc Nat Acad Sci USA 82:3707-3711

Gustafson EJ, Gardner RH (1996) The effect of landscape heterogeneity on the probability of patch colonization. Ecology $77: 94-107$

Heatwole DW, Hunt JW, Blonder BI (1992) Offshore recruitment of postlarval spiny lobster, Panulirus argus, at Looe Key reef, Florida. Proc Gulf Caribb Fish lnst 40: $429-433$

Herrnkind WF, Butler MJ IV (1994) Settlement of spiny lobsters, Panulirus argus in Florida: pattern without predictability. Crustaceana 67:46-64

Herrnkind WF, Lipcius RN (1989) Habitat use and population biology of Bahamian spiny lobster. Proc Gulf Caribb Fish Inst 39:265-278

Hermkind WF, Vanderwalker J, Barr L (1975) Population dynamics, ecology and behavior of spiny lobsters, Panulirus argus, of St. John, U.S. Virgin Islands: habitation and pattern of movements. Sci Bull Nat Hist Mus LA County 20:31-34

Higgins K, Hastings A, Sarvela JN, Botsford LW (1997) Stochastic dynamics and deterministic skeletons: population behavior of Dungeness crab. Science 276:1431-1435

Johnson DR, Hester BS, McConaugha JR (1984) Studies of a wind mechanism influencing the recruitment of blue crabs in the Middle Atlantic Bight. Cont Shelf Res 3: $425-437$

Kareiva P (1987) Habitat fragmentation and the stability of predator-prey interactions. Nature 321:388-391

Levin S (1992) The problem of patterns and scale in ecology Ecology 73:1943-1967

Lipcius RN, Cobb JS (1994) Introduction: ecology and fishery biology of spiny lobsters. In: Phillips BF, Cobb JS, Kittaka J (eds) Spiny lobster management. Fishing News Books, Blackwell Scientific Publications, London p 1-30

Lipcius RN, Stockhausen WT, Eggleston DB, Marshall LS Jr, Hickey B (1997) Hydrodynamic decoupling of spawning stock, habitat quality and recruitment in the caribbean spiny lobster: source-sink dynamics? Mar Freshwat Res 48:807-815

Little EJ Jr (1977) Observations on recruitment of postlarval spiny lobsters, Panulkrus argus, to the south Florida coast. Fla Mar Res Publ No. 29

Little EJ Jr, Milano GR (1980) Techniques to monitor recruitment of postlarval spiny lobsters, Panulirus argus, to the Florida Keys. Fla Mar Res Pub No. 37

Ludwig D, Hilborn R, Walters C (1993) Uncertainty, resource exploitation, and conservation: lessons from history. Science 260:17-36

Lyons WG (1980) Possible sources of Florida's spiny lobster population. Proc Gulf Caribb Fish Inst 33:253-266

Marx JM (1986) Recruitment and settlement of spiny lobster puerulı in south Florida. Can J Fish Aquat Sci 43: 2221-2227

Mense DJ, Posey MH, West T, Kinchloe K (1995) Settlement of brachyuran postlarvae along the North Carolina coast. Bull Mar Sci 57:793-806

Metcalf KS, Van Montfrans J, Lipcius RN, Orth RJ (1995) Settlement indices for blue crab megalopae in the York River, Virginia: temporal relationships and statistical efficiency. Bull Mar Sci 57:781-792
Milicich M.J, Meekan MG, Doherty PJ (1992) Larval supply: a good predictor of recruitment of three species of reef fish (Pomacentridae). Mar Ecol Prog Ser 86:153-166

Mojica R Jr, Shenker JM, Harnden CW, Wagner DE (1995) Recruitment of bonefish, Abula vulpes, around Lee Stocking Island, Bahamas. Fish Bull US 93:666-674

Olmi EJ III (1994) Vertical migration of blue crab Callinectes sapidus megalopae: implications for transport in estuaries. Mar Ecol Prog Ser 113:39-54

Olsen DA, Herrnkind WF, Cooper R (1975) Population dynamics, ecology and behavior of spiny lobster. Panulirus argus, of St. John, U.S. Virgin Islands: introduction. Bull Nat Hist Mus LA County 20:11-16

Paulik GJ (1973) Studies of the possible form of the stockrecruitment curve. Rapp PV Reun Cons Perm Int Explor Mer 164:302-315

Peterson CH, Summerson HC (1992) Basin-scale coherence of population dynamics of an exploited marine invertebrate, the bay scallop: implications of recruitment limitation. Mar Ecol Prog Ser 90:257-272

Peterson CH, Summerson HC, Luettich RA Jr (1996) Response of bay scallops to spawner transplants: a test of recruitment limitation. Mar Ecol Prog Ser 132:93-107

Phillips BF (1986) Prediction of commercial catches of the western rock lobster Panulirus cygnus. Can J Fish Aquat Sci 43:2126-2130

Phillips BF, Booth JD (1994) Design, use, and effectiveness of collectors for catching puerulus stage of spiny lobsters. Rev Fish Sci 2:255-289

Phillips BF, Cobb JS, Kittaka J (1994) Spiny lobster management. Fishing News Books, Blackwell Scientific Publications, London

Phillips BF, Pearce AF, Litchfield RT (1991) The Leeuwin Current, and larval recruitment to the rock (spiny) lobster fishery off Western Australia. J Proc R Soc West Aust 74 : $93-100$

Polovina JJ, Mitchum GT (1992) Variability in spiny lobster Panulirus marginatus recruitment and sea level in the northwestern Hawalian Islands. Fish Bull US 90:483-493

Roughgarden J, Gaines S.D, Possingham H (1988) Recruitment dynamics in complex lifestyles. Science 241:1460-1466

Shanks AL (1995) Mechanisms of cross-shelf dispersal of larval invertebrates and fish. In: McEdward LR (ed) Ecology of marine invertebrate larvae. CRC Press, New York, p $323-368$

Shenker JM, Maddox ED, Wishinski E, Pearl S, Thorrold SR, Smith N (1993) Onshore transport of settlement-stage Nassau grouper (Epinelhelus striatus) and other fishes in Exuma Sound, Bahamas. Mar Ecol Prog Ser 98:31-43

Silberman JD, Sarver SK, Walsh PJ (1994) Mitochondrial DNA variation and population structure in the spiny lobster Panulirus argus. Mar Biol 120:601-608

Sissenwine MP (1984) Why do fish populations vary? In: May RM (ed) Exploitation of marine communities. SpringerVerlag, Berlin, p 59-94

Sutcliffe WH (1953) Further observations on the breeding and migration of the Bermuda spiny lobster, Panulirus argus. J Mar Res 12:173-183

Tanaka M, Goto T, Tomiyama M, Sudo H, Azuma M (1989) Lunar-phased immigration and settlement of metamorphosing Japanese flounder larvae in to the nearshore nursery ground. Rapp PV Reun Cons Perm Explor Mer 191: $303-310$

Thorrold SR, Shenker JM, Maddox ED, Mojica R. Wishinskı E (1994) Larval supply of shorefishes to nursery habitats around Lee Stocking Island, Bahamas. II: Lunar and oceanographic influences. Mar Biol 118:567-578 
Thrush SF, Whitlach RB, Pridmore RD, Hewitt JE, Cummings VJ, Wilkinson MR (1996) Scale-dependent recolonization: the role of sediment stability in a dynamic sandflat habitat. Ecology 77:2472-2487

Van Montfrans J, Epifanio C, Knott D, Lipcius R, Mense D, Metcalf $\mathrm{K}$, Olmi $\mathrm{E} \mathrm{JI}$, Orth $\mathrm{R}$, Posey $M$, Wenner $\mathrm{E}$, West $T$ (1995) Settlement of blue crab postlarvae in Western North Atlantic estuaries. Bull Mar Sci 57: $834-854$

Ward J (1989) Patterns of settlement of spiny lobster (Panulirus argus) postlarvae at Bermuda. Proc Gulf Caribb Fish Inst 39:255-264

Editorial responsibility: Kenneth Heck (Contributing Editor), Dauphin Island, Alabama, USA
Wei WWS (1990) Time series analysis: univariate and multivariate methods. Addison-Wesley, New York

Witham RR, Ingle RM, Joyce EA (1968) Physiological and ecological studiess on Panulirus argus from the St. Lucie estuary. Tech Ser Fla St Bd Conserv 53:1-31

Wrona $A B$, Wiegert RG, Bishop TD (1995) Initial report of setlement patterns of brachyuran megalopae at Sapelo Island, Georgia, USA. Bull Mar Sci 57:807-820

Yeung C, McGowan MF (1991) Differences in inshore-offshore and vertical distribution of phyllosoma larvae of panulirus, Scyllarus, and Syllarides in the Florida Keys in May-June, 1989. Bull Mar Sci 49:699-714

Submitted: January 20, 1998; Accepted: August 3, 1998 Proofs received from author(s): November 6,1998 